\title{
FINANCIAL STABILIZATION: REGULATORY APPROACHES AND TOOLS FOR MONETARY POLICY
}

\section{Korneev V. V.}

\section{INTRODUCTION}

Stabilization of the financial systems under recovery of capital formation in the real sector of the economy is determined by the effectiveness of means to support the business activity, and in particular, the financing in the loan markets. For the time being, this is one of the main tasks of the governments and central banks around the world. The above requires strengthening the regulatory monitoring framework, consistent valuation and revaluation of financial assets, the gap between yields of financial transactions and transactions in the sphere of nonfinancial corporations, the expected utility and return of the funds advanced.

Lessons of the latter crisis have once again demonstrated the collapse of speculative economy fed through unsecured credit expansion. Risks of new threats while maintaining critical development imbalances remain significant (probability of a "second wave" of the crisis, the budget problems of the countries from the South of the Euro zone). Published position of OECD was disappointing, characterizing the trend of the world economy as a downward one ${ }^{1}$. That is why the current "financial instability means that the economic system, in varying degrees, allows for reproduction of crises"2. Particularly acute crisis manifested itself in the banking sector in many countries. It is also important to date that information according to the IMF estimates, the volume of bank assets write-offs only during the period 2007-2010 amounted to US\$2.2 trillions ${ }^{3}$. Despite the still unstable signs of the crisis overcoming, the basic questions remain as to how banks operate and how they have been regulated.

\footnotetext{
${ }^{1}$ Parussini, G., \& Hannon, P. (2012). OECD Warns on Global Economy. The Wall Street Journal, with the headline: Global Economy Risks New Drop, November 28, 2012. URL: online.wsj.com.)

${ }^{2}$ Коландер Д. и др. Финансовый кризис и провалы современной экономической науки. Bonpocbl экономики. 2010. № 6. С. 10-25.

${ }^{3}$ International Monetary Fund (2010). Global Financial Stability Report. URL: www.imf.org
} 
Exploring the spectrum of questions concerning financial and, especially banking, systems' stabilization, belongs to constantly relevant and popular issues. Numerous publications of foreign and domestic economists are evidence of this. However, the full list of names of researchers, which is replenished daily, can hardly be exhaustive within the presented material. However, there is a need to study the peculiarities of the financial system in Ukraine under still unresolved consequences of the recent crisis and the new role of central banks in this process.

In view of these, the object and the aim of this research are as follows: based on comparative analysis of the monetary policies implemented by the foreign central banks to identify trends and tools to stabilize the financial system of Ukraine.

\section{Activities of foreign central banks to stabilize financial systems: review}

A distinct feature to support economic development in recent years is the implementation by the major central banks the soft monetary policy (stimulating monetary policy) that can be characterized by two key elements - a) holding low interest rates by the central banks to restore loans circulation and b) buying government securities by the central banks to finance the state budgets.

Stimulating monetary policy, among other levers of government regulations of recovery processes, plays a special role as the characteristics of circulation of money largely determine the rates and proportions of economic reproduction. "Central banks have responded to the crisis by providing funding in foreign and domestic currencies. Strategic indicators were reduced countercyclical ..."4. Accordingly, there have been indicative changes in characteristics of credit operations of the central banks (through interest rate and credit channel of the transmission mechanism) and the redemption of assets in the open market (through the channel of asset prices).

The implementation of monetary policy of central banks of various countries in the 2008-2012 periods has common and distinctive features. The U.S. Federal Reserve System, during the crisis and initial recovery period, focused through monetary policy tools on easing the regulatory

${ }^{4}$ BIS (2010a). The global crisis and financial intermediation in emerging market economies. BIS Papers No 5, December 2010. URL: www.bis.org 
environment to encourage the development of the US economy. Such basic tools were the interest rate of the central bank and fixed income securities (mortgage and public) repurchase in the open market.

At the beginning of the crisis in 2008, the U.S. Federal Reserve System implemented the first program of quantitative easing QE1 in amount of US\$1.7 trillions, which was recognized as effective (when liquidity injections resulted in U.S. GDP growth up to $3.5 \%$ in 2009). However, after the deterioration of statistical data in the U.S. in 2010, the second program of quantitative easing, QE2 volume of $\$ 600$ billions was started; its results were not so obvious comparing with the results of QE1. In 2011, the U.S. Federal Reserve System started so-called "twist operations" - the replacement of short-term bonds with securities of longer maturities in its balance.

As during 2011-2012 some signs of crisis in the U.S. and Europe were obvious and even deepen, a question on starting the third program of quantitative easing (QE3) arose; and it started in September 2012. The U.S. Fed, within QE3, prolonged expected period of low (almost zero) interest rates until mid-2015, and committed to purchase mortgage bonds in amount of up US $\$ 40$ billions monthly. Typical position of the U.S. Federal Reserve System is to provide significant freedom in issues of monetary control: "government interference in matters of monetary and credit policy of central banks is undesirable because it can cause further weakening economy and rising inflation"5. The Open Market Committee of the U.S. Federal Reserve System for a long time keeps base interest rate at a record low level - In the range $0.0 \%-0.25 \%$ annually (from December 2008 to the present - January 2013). Program of debt securities repurchase were of regularly renewable nature. Largely it made possible to hold the base and other interest rates at the low level.

The monetary policy of the Bank of England is characterized by a low interest rate and support to programs of repurchase of government bonds as a part of the policy of quantitative easing. This policy also provides stimulating of business activity via corresponding monetary instruments.

In July 2012, the Bank of England increased its quantitative easing program, under which envisaged growth of reserves in the financial system to 375 billion pounds by purchasing government securities. At the same

\footnotetext{
5 Cbonds (2010). Вмешательство властей в деятельность центробанков ослабляет экономику и повышает инфляцию - глава ФРС США. URL: www.cbonds.info
} 
time, together with the government, it is envisaged to stimulate the banking sector on the condition that banks would more actively lend mortgages and other business projects.

Beginning March 2009 the Bank of England holds interest rate at $0.5 \%$ and it is not expected soon to tighten monetary policy in England.

Monetary policy of the Bank of Japan for a long time also remains soft. Since October 5, 2010, interest rate of the central bank has been set in the range $0-0.1 \%$ and remains unchanged as of January 2013. It is expected that the Bank of Japan will keep key interest rate almost zero in the future - given the existing insufficient demand in the country.

The use of such a monetary instrument as purchase of government obligations to encourage the development became more active in November 2010, when the Bank of Japan has allocated 5 trillions yen (more than US\$62 billions) for immediate purchase of government securities. In August 2011, Japan's central bank decided to increase the volume of the program of repurchase assets (government and corporate bonds) up to 50 trillions yen (US\$648 billions).

The European Central Bank (ECB) carries out regionally consolidated interest rate policy, purchases obligations of sovereign and other debtors, provides loans secured by bonds issued by countries-member of the Euro zone. However, the combination of levers of monetary and fiscal policy on economic dynamics is not always a compromise; that gave grounds to the ECB representative in November 2011 to declare that adaptation of monetary policy to the fiscal policy was unacceptable. The ECB key interest rates remained at historic minimum level of $1 \%$ for almost two years from May 2009 to 7 April 2011, when the ECB raised it to 1.25\%. However, a few months later - In early November 2011 the ECB key rate was again lowered to $1 \%$, and from July 7, 2012 - to $0.75 \%$ due to poor economic conditions.

Dynamics of economic activity in the euro zone has been slowing down due to the tightening fiscal policy (as a consequence of the problems of the Southern euro zone - Portugal, Ireland, Italy, Greece, Spain - socalled peripheral group "PIIGS"). Stabilization of the financial state of the countries with problems in public finance through purchase of sovereign bonds (Program of support of the financial sector of the EU countries implemented within the framework of the EU-IMF plan, volume 750 billion euros) provided the necessary liquidity of markets in the Euro zone. The European Financial Stability Fund (EFSF), which funded 
support to Portugal and Ireland, during 2012 - the first half of 2013 gradually transformed into the Financial Stability Mechanism (MFS). The MFS has to replace the EFSF - as an option to replace temporary mechanism with permanent one.

ECB intervened in markets of sovereign and corporate bonds of those countries where there have been high volatility of returns. Further on the ECB implemented a variety of tools to support liquidity. In 2012, when the situation in the markets of sovereign debt in peripheral euro zone countries obviously deteriorated, the ECB faced with a difficult dilemma: while it was necessary to continue to implement monetary anti-crisis measures, inflation risks increased.

The Central Bank of China (CBOC) devalued its currency in September 2008 and since then has kept the Yuan low against the U.S. dollar and a stable exchange rate against the euro, while maintaining a fixed proportion of sovereign bonds of EU countries in the portfolio of its international reserves.

Functioning of the world economy as a macro system is periodically accompanied by so-called "currency wars", when exchange rate policies of some countries aimed to support their exports at the expense of balancing foreign economic interests. That is, both the U.S. and China are moving in the same direction. A new term has been created - Chimerica - a symbiosis of the first letters of the names of the two countries - China and America. However, there is here also a parallel with the word chimera.

In the international environment becomes apparent gradual activation of segment of Islamic finance with substantial specific related businesses activities. Economic and other developments results in Muslim countries consider the characteristics of Islamic model financial markets.

Islamic financial institutions primarily banks substantially covering not only local but also at international markets. The estimated capacity of financial assets in operating of Islamic banks until recently was about 1 trillion dollars that gradually was provided initially $15 \%$ and then $23 \%$ annual growth rate (in western countries the same rate before the latest crisis was on average $10 \%){ }^{6}$

Operation of Islamic finance is based on religion and using of the principles of Islamic Sharia law. In Islamic countries are characterized by unity of religion (faith) and such elements of social structure as the

\footnotetext{
${ }^{6}$ Increased cooperation between the Pacific and the Middle East // BFCI. 2007. № 67.
} 
organization of power, family, economic and other relations. In such circumstances, "Sharia as laws complex" identifies the functioning of Muslim society. As part of the Far Eastern religious and ideological structures religion is not so much higher sacred value, and mostly studies close to the philosophical, in Indonesia and Malaysia official doctrine included the provisions of Islam.

Islamic finance initially expansionary formed due to the formation of significant positive trade balance of Islamic Petroleum Exporting Countries during the 1973-1974 and 1979-1980 years that was relevant in the future, thereby increasing the competitiveness of the Persian Gulf. But gradually the economic and other fields increasingly manifest and other factors including the desire to ensure recognition of the "greater Islamic identity".

In the economic sphere Islam puts in the first place enterprise qualities but not the capital. The main feature of financial activities in Islamic countries is that the contracting agreements there is a prohibition on interest payment for conducting financial transactions - income usually paid as a result of participation in profits and not interest charges. In this sense, "made distinguish usury (to get a percent of capital) and profits is a result of human labor."7

Islamic financial institutions have not charge a fixed fee payment and a conclude contracts in the form of participation in the capital, acquisition of property intermediaries and resale to the customer in installments to pay for the increased risk. For the accumulation of resources instead of traditional deposit accounts contracts are used for mutual trust basis and such instruments are used payment of which is fixed in advance and are based on the distribution of prospective profits from a financial institution ${ }^{8}$.

The use of Islamic financial instruments shows their actual "no credit" nature, when prudently in other terms value component of transactions subject to considerations of mutual economic development rather than strictly specified capitalization of prepaid funds. This sacred character entity as opposed to impersonal kind of commercial is dominant.

Within the institutional framework of the Islamic financial model the most developed is banking (Islamic banking). Islamic banks have hardly suffered from the recent financial crisis there are no examples of their failure or refusal of payment and returning of deposits.

\footnotetext{
${ }^{7}$ Voznyy, K. Z. (2010). Islam and the modern economy: a comparison and relations. Economic Theory, no 4 , p. 14.

${ }^{8}$ Ermolov, M. O. (2007). Islamic Finance: interoperability. Business and banks, no 3, pp. 7-8.
} 
Basic financial services of Islamic banks based on making and maintenance contracts for: a) purchase and resale of goods to the customer's order (murabaha), b) the provision of capital to the client and implementation of the bank with the functions of the company management (mudaraba) c) bringing of the incorporated capital of a bank and of client for financing of projects with proportional distribution of incomes and losses of the parts (musharaka), d) the acquisition of goods, mainly of agricultural,with a delayed period of supply (Salaam); d) interest-free loan for charitable purposes is secured by pledge (Card Al-Hasan), e) the bank financing of equipment or storage of products for an agreed price with the client which is actually a tool to finance supply (istisna) f) leasing (idzhara) g) lease contract with the possibility of buying lease (idzhara va-iktina). Generally Islamic financial instruments as compared to other are less risky because the bank has always shared the risks with the client.

The Islamic financial system is also characterized by the absence of the Islamic interbank market ${ }^{9}$. Time transaction with using derivatives are prohibited. Since all transactions strictly related to the transactions of tangible assets so all speculations is minimal. Separate specific activities of Islamic financial institutions is to ban funding for gambling, alcohol and tobacco production.

Among the financial instruments Bonds "sukuk" is a medium-term interest-free bonds that are issued as appropriate initiators in Muslim and in other countries and are calculated on Islamic investors. Structure of production involves participation of investors and issuers in the ownership of certain assets consequently bonds "sukuk" provided assets. The most common version of issuing bonds after their placement takes investors in bonds "For Rent" (as a property) and at the same time agrees to buy them in the same investors at the end of term of appeal by paying the agreedupon "rent" (as for using of a property).The last determines the yield of bonds "sukuk" which can be fixed or floating - for example to be oriented on dynamic rate LIBOR. Formally none of the parties of the agreement does not pay or receive interest charges. Nomination of bonds "sukuk" is available in different currencies and of the underlying asset may include revenue or leasing contracts for the supply of certain material resources.

Development of segment bonds "sukuk" although "totally changed Islamic finance", ${ }^{10}$ but still remains different across countries. The largest

\footnotetext{
${ }^{9}$ Maslennikov, V. V. (2001). Foreign banking systems. M. : TD "Elite 2000", 351 p.

${ }^{10}$ Ymam, P., Klodar, K. Is it useful for economic growth? URL: http://www.imf.org/external/russian/ pubs/ft/fandd/2010/12/pdf/imam.pdf
} 
issuer of bonds "sukuk" is the government of Malaysia (28 billion dollars., or $87.5 \%$ of total emissions at the end of 2005), the relevant corporate including bank loans during the 2003-2005 was 5,5 billion dollars ${ }^{11}$. According to recent estimates, the global amount of the bond market "sukuk" reached 24 billion pounds ${ }^{12}$.

New separate elements in Islam finances need additional study. We know that business activity around the world in holiday periods is usually reduced.

However, despite progress the financial system in Muslim countries are characterized by relatively simplified institutional structure and unification used financial instruments. It is dominated by large, particularly family owners, investors in equity and there are no many retail investors and speculators. These aspects indicate the relatively closed nature and limited market liquidity where the Islamic financial model is used.

Historically, long time Muslim countries was under the influence of Western practice of customer service so in the second half of the twentieth century. people actually enjoyed financial and banking services. The first Islamic savings banks fund "Mit Garm Bank" started back in 1963 - first in Egypt to serve the peripheral regions of the country and later in Malaysia to accumulate savings for Hajj.

However, the actual beginning of the Islamic banks is a creation of Islamic Development Bank ("Islamic Development Bank") in Saudi Arabia in 1975 which led to the rapid formation of other Islamic banks in the second half of the 70-th of $20^{\text {th }}$ century. This are a "Dubai Islamic Bank" in the UAE (1975), "Faisal Islamic Bank" in Egypt and Sudan (1977), "Bahrain Islamic Bank" in Bahrain (1979).

Modern Bahrain and Malaysia are the centers of Islamic finance and banking activity (both are considered to be perspective Muslim financial centers). As Bahrain concentrates 35 Islamic banks - the largest number compared to other Muslim countries (for comparison, in Kuwait - 15, in the UAE - 14 in Saudi Arabia - 10, in Qatar - 3). At the end of 2006 in the world there were more than 300 Islamic banks with a market capitalization of over 13 billion dollars and assets of 262 billion dollars.

In many countries there are 400 Islamic equity funds and 250 mutual funds - managed by the first of them is over 5 billion dollars, and some

\footnotetext{
${ }^{11}$ Pakhomov, S. (2007). The phenomenon of international market development "Islamic bonds". REM, no $7-8$, pp. 97.

${ }^{12}$ London - capital of Islamic finance. URL: http://islam.com.ua/news/5074/\#
} 
hold shares worth 11 billion dollars. In Malaysia, specially created zone offshore Labuan as a regional investment oasis. Among Islamic banks issuing bonds "sukuk" actively positioned the Islamic Development Bank, Islamic Bank Dubai Islamic Bank Abu Dhabi. In order to finance government projects in Sudan and Iran issued by the government shortterm bonds (also on the principles of participation).

However, Islamic banking remains quite fragmented, and even the largest Islamic banks in terms of yield to Western capitalization - the average amount of capital the overwhelming share of Islamic banks does not exceed 25 million dollars.

Operations and services of Islamic financial institutions gradually cease to be the province only of participants from Muslim countries. According conference on the development of Islamic finance in Japan (March 2008), noted to be perspective “... at high oil prices and expansion of capital markets Islamic finance and Islamic financial mechanism will have a growing influence on world financial markets in the future"13. However, it still be significant constraints remains of spreading of Islamic finance in other countries.

Firstly, there is some closeness business information, limiting the analysis as a host of financial management of Islamic financial institutions, types of risk and asset structure. K. Rohoff noted that "the main reason why the default of Dubai World happened was in liquidity of UAE finances ${ }^{14} \ll$. Informative problem due to the fact that there was no standards of financial reporting to Islamic financial institutions. In some countries AAOIFI (Accounting and Auditing Organization for Islamic structures) are used. In other countries other standards are used ${ }^{15}$.

Secondly, there is no proper legal framework, which should combine the requirements of the activities of the financial system of another country, to required of Sharia standards. As a result, financial markets and institutions in different countries are looking for opportunities of mutual adaptation conditions and management tools.

Western banks are diversifying their range of financial instruments with using of Islamic law which open and maintain so-called "Islamic windows" - bank departments which provides services in accordance with

\footnotetext{
${ }^{13}$ URL: http://www.muslim.ru/1/cont/4/5/982.htm

${ }^{14}$ Rogoff, K. (2009). The limits of Dubai. Investgazeta, no 48, 7-13, 12.

${ }^{15}$ Tahibyekov, M. (2009). The features and advantages of Islamic banking. Financial Markets, no 11, p. 34.
} 
Shariah rules. This contributes to avoid recurrent problems of liquidity in the markets of USA and Europe.

Examples of such interest and its practical implementation is to engage in a "sukuk" German bank "Saksonia-Anhalt" in 2004 more than 120 million dollars loans and similar loans of mining company in the U.S. "East Cameron Gas Company" 165 million dollars under the guarantee of its own reserves of carbohydrates. Road-shows of Malaysian bank SIMV in East and Southeast Asia in early 2008 had considerable success.

In order to ensure the competitiveness Western banks open departments in Muslim countries. Thus, in 1997, the U.S. "Citigroup" has established a subsidiary "City Islamic Investment Bank" in Bahrain with a capital of 20 million dollars. And investment in specialized Islamic fund reached 1 billion dollars.

Among of European banks, the first English "HSBC" in 2003 began offering to modify mortgage services with regard to their specificity in Islamic countries: bank acting on behalf of the customer in acquiring real estate property that is similar to leasing. In the Islamic financial markets have a business interests such banks as "Citibank", "Deutsche Bank", "ABN-Amro", "Societe Generale", "ING", "Chase Manhatten", "JP Morgan" and other banks that take into account the Islamic law. Thus, in most Muslim countries, along with Islamic banks operate western banks. Only financial systems to Iran and Sudan are based solely on national institutions.

On the other hand in recent decades and years have seen exyra activity of Islamic banks and other institutions in the market non - Muslim countries. Islamic financial institutions gradually cease to be regional and gradually spread its extraterritorial service. Thus, in 1978 in Switzerland have been reported "Islamic Banking System International Holding", and "Islamic Finance House" in Luxembourg - the first in the West Islamic financial institutions that are actually a base for external dissemination of Islamic finance. Later, was incorporated group "Dar al-Mal al-Islami Trust" in 1981 in Switzerland with a registered capital of 1 billion dollars, which founded banks in Europe and Africa. In 1982 the Saudi investment company "Al-Baraka Investment Company" purchased "Hargrave Securities" in the UK - an organization that had a license to operate to attract population deposits. Later it was created based Islamic bank "Islamic Bank of Britain", which in 2004 issued its shares on the London 
Stock Exchange. Before the latest crisis - in 2008, banking services that comply with Shariah guidelines provided in London 21 traditional banks. Britain is becoming a kind of center for Islamic bankin gin Western countries. However, Islamic financial instruments are distributed in continental Europe. In particular, in France in September 2009 adopted a special law on the possibility of emission of the country corporate Islamic "sukuk" bonds which release is expected in 2011.

Thus, Islamic financial institutions in the western markets operate mainly using three forms - investment companies, investment companies and financial groups in Euro countries. Unsuccessful attempts to start the experience of Islamic insurance (takaful) in Europe: founded in 1983 in Luxembourg Takafol SA and in London Takafol UK Ltd failed to function as insurance.

Until recently, the Islamic financial model was perceived as more resistant to disasters market compared with other financial models and in "crisis year" (autumn 2008 - autumn 2009) analysts continually analyze its advantages. However, in early December 2009 when it was announced about a suspension for 6 months of paying of the debts of the state corporation of Dubai "Dubai World" of 26 billion dollars. It became clear that the real estate market is one of the most dynamic Muslim countries has become a new example of soap bubbles. Cash gap formed after the price real estate in the early fourth quarter of 2009 decreased by 53\% compared with 2008, and income from the exploitation of Dubai World hotels was unable to cover interest payments on loans received earlier. The December (2009) Panic in world markets was cost because of outstanding debt of Dubai World.

Mass demonstrations against the ruling regimes due to uneven distribution of income between population groups in terms of Muslim countries (25.01.2011, the first in Egypt and later in other countries), although it had clear political character, but it was showed the main aspects of vulnerability the Islamic world. For example, in Egypt every day political crisis in January and February in 2011, according to Credit Agricole, costing the national economy 310 million dollars ${ }^{16}$. There had been a week-long suspension of operation of banks, since their discovery in early February had set limits on cash and cash collection for security reasons and used military transport aircraft. Central Bank of Egypt to

${ }^{16}$ URL: http://banker.ua/bank_news/banks/2011/02/07/1180447042 
compensate depositors removed funds allocated 854 million dollars from its own reserves.

However, the practices of Islamic financial model and Islamic banking on the formation and maintenance of segment established under the right conditions of financial services has become the heritage of international significance. Capital coming from Muslim countries in Ukraine's financial sector is a matter of time - the internationalization of economic activity in different areas is confirmation of it. After the last crisis, it is clear that to obtain additional resources from the western markets for fixed credit basis is becoming more problematic. In modern terms the positive aspects of Islamic financial model, particularly in terms of transparency of bank transactions and investments worth spreading in the domestic financial and banking management.

\section{The practice of stabilization of banking systems in Ukraine}

In Ukraine, the stabilization of the banking sector has been ensured by the National Bank of Ukraine (NBU) in framework of indicative changes of monetary and exchange rate policy. These changes, in turn, were conditioned by the processes in both external and domestic financial markets. Regulatory vector of the NBU actions during the crisis was intended to support liquidity in the banking system of Ukraine; i.e. when the anti-crisis monetary policy shifts reflected in activation of the refinancing mechanisms, curbing the outflow of funds outside the banking system with variable use of interventional tools, changes in reserve requirements and interest rate policy.

A discount rate, among set of the NBU's interest rate tools, should play a more active role. Today the value of money in Ukraine is still mostly caused by the changing market conditions and risks, and to a lesser extent by the interest rate policy of the regulator. In the current 2019, the discount rate is maintained at $17.5 \%$ (at the time of the subtraction of the material, 2nd quarter 2019) ${ }^{17}$.

Therefore, changes in interest rate and refinancing rates in financial markets are not transformed directly and quickly into changes in rates on bank loans and deposits. However, it is economic turmoil in recent years, and particularly the lessons of the financial crisis that demonstrated the need to enhance the role of interest rate policy: the main channel of the

\footnotetext{
${ }^{17}$ URL: www.bank.gov.ua
} 
money supply should be the refinancing of commercial banks and the main regulator - interest rate (refinancing rate). Today, the role of the NBU discount rate, according to the IMF Memorandums, has been transformed from the signal beacon of the value of money (from 2016) to a key indicator of monetary policy (from 2018 to the present).

The reason why the discount rate in Ukraine insufficiently serves as "a guide price of money" and is limitedly demonstrative indicator, lies in the peculiarities of the functioning of other segments of the financial market and the pricing of those assets. Thus, primarily this applies to opaque domestic securities markets (especially stock markets), resulting in the price of the asset little corresponding to their values. Under existing irrelevant information, price for stock assets actually is a "thing in itself" and does not reflect the potential investment value of the assets. It should be noted also that banking systems of around the world more widely use trading with participation of the central banks in the open market (i.e., foreign exchange interventions, repo agreements), where the role of interest rate policy is clearly subordinate.

Changes in the NBU discount rate in recent years geared toward the reduction of inflation risks, the need to encourage capital inflows into Ukraine and at the same time to curb its outflow. In general - to reduce the money supply and monetary constraints. However, money for many borrowers remains deficit due to their high cost, as businesses and households suffer from a lack of working capital.

Cooperation with the IMF plays an important role in the monetary policy of the NBU. This is necessary both for balancing the balance of payments and for replenishing the central bank's international reserves and maintaining financial stability. Separate considerations in this regard.

Also cooperation with the IMF is important as the litmus positioning of debtors in the international debt markets. Such a litmus may be both positive and negative in terms of Stand-by or Extended Fund Facility-EFF (Extended Financing Mechanism). The last program is currently being implemented in Ukraine.

IMF loans - this is a guaranteed debt of the state, the proceeds of which are directed to replenish the NBU's international reserves (this is usually, but sometimes the recipient of funds may also be the Government - in the latest history of Ukraine such examples were, and then the debt is classified as direct). Receipt of IMF loans balances the 
balance of payments when receiving funds from a financial account in the presence of problems (negative balance) of the current account, mainly due to "swings" of export-impot operations.

The danger of IMF loans is that, the presence of special extra lending terms that limit the sovereignty and autonomy of borrowers. Credit as an instrument becomes a "needle", without the subsequent injections of which the economy ends with no foreign exchange earnings, and the balance of payments requires an endogenous and permanent replenishment of funds in foreign currency.

Often, replacement of some (old) loans with new ones, ie receiving new tranches is spent on servicing and repayment of debts from past periods.

From the point of view of compliance with the economic and financial security of the state, gradually contacts and negotiating position of Ukraine with the IMF should be translated into the consultative plane as an important participant of a group of international financial organizations. That is, prospective Ukraine is not a debtor, but a side of an advisory dialogue. It should be a common goal of the central bank and the executive (the government).

It should be noted that balancing the balance of payments balance is a task not only of the central bank, but also of the Government. It is the Government that is able to provide a surplus in the export / import pair. The Central Bank does not deal directly with foreign economic policy. Therefore, reducing the dependence on IMF loans is not only a task for the central bank. This is a joint task of the Central Bank and the Government.

The central bank of Ukraine, through its own monetary policy, can take a more active part in lending processes. Thus, one of the effective instruments of indicative financing of the priority projects of economic development may be the target emission of the central bank - the National Bank of Ukraine. Such target emission (directly or through the mechanism of targeted government bonds) should be directed towards refinancing of bank loans issued to enterprises and institutions whose investment projects meet pre-determined criteria.

The main benefits of this are the possibility of implementing the necessary measures of state economic policy in the capital markets, banking system, investment, international cooperation, public-private partnership. 
At the same time, the stabilization of the financial system and the real sector of the economy is possible due to the implementation of certain priority investment-credit (not speculative) agreements, designed to solve national issues of economic development.

The use of updated lending schemes for prime development projects with the participation of the central bank (and the Ministry of Finance) will allow the implementation of tools to protect the interests of the state, primarily in terms of control over the targeted use of funds and their proper direction.

The scheme of the target issue does not bear the risks of "leakage" of financial resources into areas that may create a threat to financial stability the currency market and other possible speculative operations. Thus, the target emission in such conditions will not be able to provoke "out-of-thebox" inflationary processes, or other manifestations of price and financial instability.

Under the conditions of limiting financing from external sources (but not only this), the main emphasis should be placed on the development of the domestic market of long-term financial, and, above all, credit resources. Under the weighted regulation of the NBU, the commercial activities of banks should go beyond mediation and acquire investmentcatalytic features. The proper circulation of the loan will resume and "restart" other development financing instruments. This is necessary both for the normalization of the cycle of credit resources, and for safeguarding the financial system from excessive volatility in the market situation.

\section{CONCLUSIONS}

Financial systems are constantly in need of crisis monitoring - and primarily preventive one, - which is in line with international practice ${ }^{18}$. The growth of markets (including loan basis) must be supported by and balance with real savings rather than speculative multiplication of value of assets.

Despite the strengthening of relationships in the context of globalization and increased institutional role of international summits (e.g., in the form of G-20), it becomes clear that each country should independently overcome the crisis and to stimulate their economies

18 BIS (2010b). Financial stability: 10 questions and about seven answers: Speech delivered by Mr J. Caruana. General Manager of the BIS, at the 50th Anniversary Symposium of the Reserve Bank of Australia, Sydney, 9 February 2010). 
according to their actual capabilities. Resource and institutional constraints of government regulation and recovery of financial markets (in terms of limits on funding stabilization programs by central banks at the expense of monetary resources and government budgetary resources while maintaining the disproportionate development of some euro zone countries under a single institutional framework of the EU) remain significant factors in the development of financial systems in various countries.

Obviously, the Anglo-American and continental (euro zone) financial models confirm to maintain their individual characteristics. Islamic banking is actively developing. And there is a growing demand for the services of Islamic banks. Question of convergence of these models may not be comprehensive despite the increasingly widespread universalization of regulatory and business activities. Universal model of markets and banks showed the presence of clear warnings and restrictions of its operation since it bears the risks associated with the concentration of resources in a single financial center (conglomerate). Universal institutes' presence is justified under the stable conditions and is risky during the crisis.

Ukraine needs not fragmentary but systemic reform of the financial sector in Ukraine as a whole, e.g. banking system, non-banking institutions and business infrastructure. Given the limitations of funding from external sources (but not only this), the main emphasis should be made on the development of the domestic market of financial and other resources of long maturity, including securities market. An activity of the institutional investors should go beyond mediation and get investment catalyzing signs. This is extremely necessary for the normalization of loan and investment cycle and protection of the financial system against external threats of destabilization.

Due to the fact that the price of money as a resource are formed taking into account the peculiarities of development of related segments of the financial market, Ukraine requires effective measures to improve the functioning of financial markets, including the stock market; in particular the transparent pricing of fund assets and disclosure of information on implementation of trade agreements.

Purchase of government bonds by central banks should be considered as an exceptional and not a permanent measure. Otherwise, risks of budget management are transferred to responsibilities of the central bank through monetization of the budget deficit. However, central banks 
cannot be fire creditors of the first instance - they are institutional lenders of the last resort.

Loose stimulating monetary policy needs to be balanced by tight fiscal policy. In other words, increasing the money supply through interest rate and loan channels of the transmission mechanism of monetary policy requires balancing the amount of money in terms of limiting the availability of funding through budget expenditures.

In Ukraine, resumed exports and stimulated and solvent domestic demand should be key factors in stabilizing the currency. This would let to adjust the existing imbalances in the balance of payments (in terms of peculiarities of its current account and capital account). Given the still limited funding from external sources (but not only this), the main emphasis should be on the development of domestic market of long-term financial resources. The effective resolution of monetary tasks is possible in the mainstream of improving macroeconomic indicators of economic development.

\section{SUMMARY}

Financial stabilization requires active participation of state structures in this process. Special role belongs to central banks and monetary policy. Banks are major providers of changes in the financial sector. Modern changes in development on the basis of dichitalization that confirmation.

The paper deals with issues of ensuring stability of foreign and domestic financial systems. The effectiveness of monetary tools used by the central banks to restore economic development has been analyzed. The resulting estimates and expectations, with emphasis on necessary stabilization measures in Ukraine, have been substantiated.

\section{REFERENCES}

1. Parussini, G., \& Hannon, P. (2012). OECD Warns on Global Economy. The Wall Street Journal, with the headline: Global Economy Risks New Drop, November 28, 2012. URL: online.wsj.com.)

2. Коландер Д. и др. Финансовый кризис и провалы современной экономической науки. Bопросы экономики. 2010. № 6. С. 10-25.

3. International Monetary Fund (2010). Global Financial Stability Report. URL: www.imf.orgBIS (2010a). The global crisis and financial 
intermediation in emerging market economies. BIS Papers No 5, December 2010 // www.bis.org.).

4. Cbonds (2010). Вмешательство властей в деятельность центробанков ослабляет экономику и повышает инфляцию - глава ФPС США. URL: www.cbonds.info

5. Increased cooperation between the Pacific and the Middle East / BFCI. 2007. № 67.

6. Voznyy, K. Z. (2010). Islam and the modern economy: a comparison and relations. Economic Theory, no 4, p. 14.

7. Ermolov, M. O. (2007). Islamic Finance: interoperability. Business and banks, no 3, pp. 7-8.

8. Maslennikov, V. V. (2001). Foreign banking systems. M. : TD “Elite 2000”, 351p.

9. Ymam, P., Klodar, K. Is it useful for economic growth? URL: http://www.imf.org/external/russian/pubs/ft/fandd/2010/12/pdf/imam.pdf

10. Pakhomov, S. (2007). The phenomenon of international market development "Islamic bonds". REM, no 7-8, pp. 97.

11.London - capital of Islamic finance. URL: http://islam.com.ua/ news/5074/\#

12. URL: http://www.muslim.ru/1/cont/4/5/982.htm

13. Rogoff, K. (2009). The limits of Dubai. Investgazeta, no 48, 7-13, 12.

14. Tahibyekov, M. (2009). The features and advantages of Islamic banking. Financial Markets, no 11, p. 34.

15. URL: http://banker.ua/bank_news/banks/2011/02/07/1180447042

16. URL: www.bank.gov.ua

17. BIS (2010b). Financial stability: 10 questions and about seven answers: Speech delivered by Mr J. Caruana. General Manager of the BIS, at the 50th Anniversary Symposium of the Reserve Bank of Australia, Sydney, 9 February 2010).

\section{Information about author:} Korneev V. V.

Doctor of Economics, Professor, Department of Finance and Accounting, V. I. Vernadsky Taurida National University 33, John McCain str., Kyiv, 02000, Ukraine 